University of Louisville

ThinkIR: The University of Louisville's Institutional Repository

$5-2012$

\title{
Measuring and predicting overqualification from 1972-2010 : a secondary analysis of the pooled general social survey.
}

Henry E. Curtis

University of Louisville

Follow this and additional works at: https://ir.library.louisville.edu/etd

\section{Recommended Citation}

Curtis, Henry E., "Measuring and predicting overqualification from 1972-2010 : a secondary analysis of the pooled general social survey." (2012). Electronic Theses and Dissertations. Paper 305.

https://doi.org/10.18297/etd/305

This Master's Thesis is brought to you for free and open access by ThinkIR: The University of Louisville's Institutional Repository. It has been accepted for inclusion in Electronic Theses and Dissertations by an authorized administrator of ThinkIR: The University of Louisville's Institutional Repository. This title appears here courtesy of the author, who has retained all other copyrights. For more information, please contact thinkir@louisville.edu. 


\title{
MEASURING AND PREDICTING OVERQUALIFICATION FROM 1972-2010: A SECONDARY ANALYSIS OF THE POOLED GENERAL SOCIAL SURVEY
}

By

Henry E. Curtis

B.S. Sullivan University, 2009

\author{
A Thesis \\ Submitted to the Faculty of the \\ College of Arts and Sciences of the University of Louisville \\ In Partial Fulfillment of the Requirements \\ For the Degree of
}

Master of Arts

Department of Sociology

University of Louisville

Louisville, Kentucky

May 2012 
MEASURING AND PREDICTING OVERQUALIFICATION FROM 1972-2010: A SECONDARY ANALYSIS OF THE POOLED GENERAL SOCIAL SURVEY

\section{By}

Henry E. Curtis

B.S., Sullivan University, 2009

A Thesis Approved on

April 20, 2012

By the following Thesis Committee:

Hiromi Taniguchi, Thesis Director

Cynthia Negrey 


\section{ABSTRACT \\ MEASURING AND PREDICTING OVERQUALIFICATION FROM 1972-2010: A SECONDARY ANALYSIS OF THE POOLED GENERAL SOCIAL SURVEY}

Henry E. Curtis

April 20, 2012

The rate of overqualification, defined as a person having more education or skills than their job requires them to have, has continued to grow since the issue was first identified as a significant problem. Though evidence that suggests the rate of overqualification has continued to grow, American sociologists have shown little interest in the area in most recent years while their international counterparts have looked at the issue in abundance. This study finds that the amount of the workforce overqualified for their jobs from 19722010 has steadily increased and possible predictors of the issue are addressed. The region where one lives and parents' education may be significantly related to overqualification. In addition, a curvilinear regression analysis shows an interesting trend that occurs with overqualification and age. From binary regression analyses and a curvilinear analysis of overqualification surprising results that do not support theory and other expected hypotheses are found. 


\section{TABLE OF CONTENTS}

SECTION $\quad$ PAGE

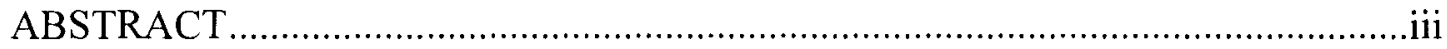

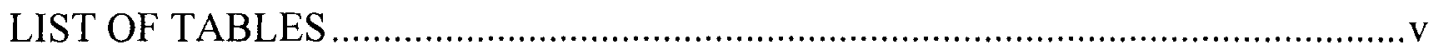

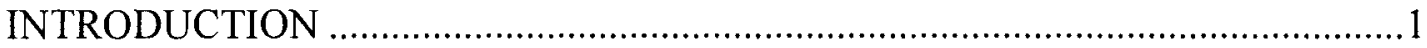

LITERATURE REVIEW ...................................................................................

Definitions of Overeducation, Overqualification, and Underemployment.............4

Measurement of Overqualification ........................................................................

History of Overqualification, Overeducation, and Underemployment...................9

Predictors, Causes, \& Effects............................................................................13

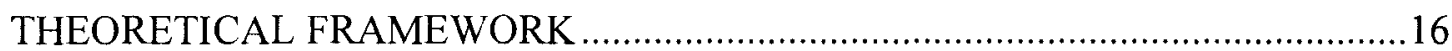

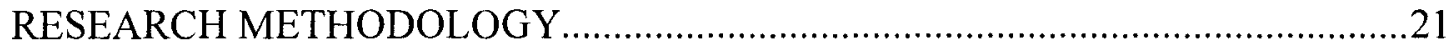

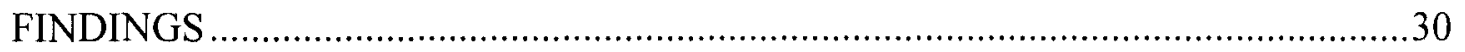

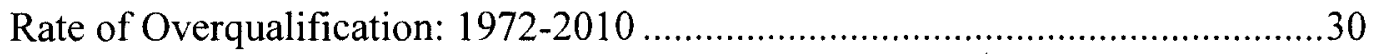

IV's Relationship to Overqualification..............................................................3

Binary Logistic Regression Findings ................................................................35

A Further Analysis of Age as A Predictor ......................................................40

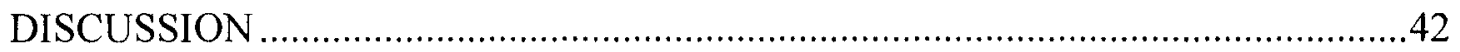

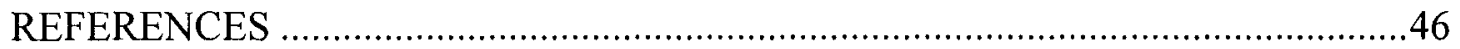

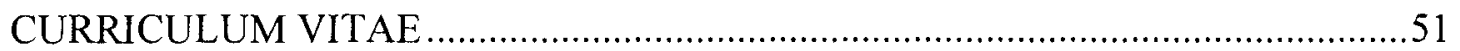




\section{LIST OF TABLES \& GRAPHS}

TABLE

Table 1 6

Table 2 .22

Table 3 23

Table 4 .28

Graph 1 31

Graph 2. 32

Table 5 .33

Table 6 34

Table 7 .36

Table 8 . .40

Graph 3 .41 


\section{INTRODUCTION}

In recent years American sociologists have rarely looked at the issues of overqualification, overeducation, and underemployment, while their European counterparts have paid much more attention to the issues (for international work see Verhaest and Omey 2006; Allen and Velden 2001; Battu and Sloane 2000; Beneito et al. 2002; Büchel 2002; 2004; Groot and Brink 2000; Rubb 2003). These three concepts can be defined as an employee having more education or skill than their job requires. There is a lack of sociological research comparing underemployment rates to education (Vaisey 2006). The American research that does surround overqualification, overeducation, and underemployment shows that an increasing number of college graduates are employed in jobs that do not require as much education or skill as they have acquired through their education, and they are often in jobs which are temporary, part-time, or ones that offer little or no upward mobility (Clogg and Shockey 1984; Feldman and Turnley 1995; Vaisey 2006).

Research shows that a large and growing number of U.S. workers are overqualified for their jobs (Vaisey 2006). This appears to be the result of the widening gap between a large expansion in educational attainment and only modest increases in job educational requirements over the past forty years (Vaisey 2006). If the level of educational attainment is increasing faster than the educational level required to do available jobs, then there may be adverse consequences for the macro economy. In addition, the 
growing rate of overqualification in the U.S. may give rise to other adverse consequences, particularly for individuals, especially those in lower income families or those among other disadvantaged groups (Vaisey 2006).

These issues are important for many reasons. If the rate of overqualification is increasing then there may be fewer jobs for those in society with fewer skills and less education. This can mean that with the growing rate of overqualification, we may find that those from less affluent, or other disadvantaged backgrounds may have a harder time finding jobs because positions that used to require little to no skill, and perhaps only a high school education, are now being filled by those who are overqualified (Vaisey 2006).

Secondly, more and more students are taking on the burden of student loans to finance their college education. Reed (2011) tells us that student debt now burdens 66 percent of college graduates as of 2010 , with an average debt of $\$ 25,250$ per student. Aggregating all of the student debt in the creeping up on 1 trillion dollars ("Student Loan Debt Clock" 2012). Coupling this ever increasing student loan debt with more and more students being overqualified for their jobs may lead to higher student loan default rates. The reason for this is because overqualified workers are often paid less than their qualified counterparts (Vaisey 2005). This can result in more college graduates not being able to pay off their educational debt.

Another reason why more attention directed towards overqualification is warranted is because it is important for the economy and workforce that people are trained and educated with the skills necessary to occupy the jobs that the job market has available. Otherwise, the labor force will be burdened with skill mismatch.This could 
lead to specific jobs not being occupied because the labor force has not been equipped with the skills to work them.

The sociological and economic implications of overqualification are vast (Vaisey 2006). Sociology can help to compliment an economic understanding and vice versa (Gibbons 2005). Indeed, sociology can help lead to a better and more complete interpretation of economic issues such as overqualification (Vaisey 2006). While international sociologists have found overqualification maintained interest in overqualification for international work see (Verhaest and Omey 2006; Allen and Velden 2001; Battu and Sloane 2000; Beneito et al. 2002; Büchel 2002; Groot and Brink 2000; Rubb 2003) American sociologists interest in overqualification has been limited to few studies in recent years (Vaisey 2006; Livingstone (a Canadian sociologist addressing overqualification in the U.S. and Canada) 1999; 2004; Feldman 1995; 1994; Halaby 1994). 


\section{LITERATURE REVIEW}

\section{Definitions of Overeducation, Overqualification, and Underemployment}

Underemployment is defined relative to some standard of employment and as a poorer, substandard, or lower quality type of work than that for which one is qualified for (Feldman 1996). Sullivan and Hauser (1979) categorized people as underemployed if they were overeducated or their jobs required less skill than they had obtained in the work force. In some cases, underemployment is defined relative to the employment experiences of others with the same education or work history. In other cases, these concepts are defined relative to the person's own past education or work history (Feldman 1996).

Most economists use wages to determine underemployment (Feldman 1996). Zvonkovic's (1988) definition of underemployment is stated as, earnings that are at least 20 percent less than their earnings in their previous job, which is downward mobility. Other economists have defined these concepts in terms of erratic employment or in terms of employment mismatched with education and training (Feldman 1996).

Overqualification or overeducation occurs when a worker is more educated than is needed for his or her job (Burris1983; Vaisey 2006). This is consistent with previous conceptualizations of overqualification by economists, sociologists, psychologists, and organizational behavior researchers (Feldman 1996). In addition, overqualification and 
overeducation can be defined as when the individual is involuntarily employed outside his/her area of education or expertise (Feldman, 1996).

While existing literature may apply any one of the three terms discussed above, they all have a lot in common, are very closely related, and are even sometimes synonymous. Indeed, Sullivan and Hauser (1979) define underemployment as being overeducated or overqualified. Because of the close relationship that exists with these three concepts through the literature, I utilize the three terms interchangeably, focusing primarily with overqualification for consistency.

\section{Measurement of Overqualification}

Of crucial importance to the concept of overqualification is in how it is measured. Overqualification is difficult to measure and the primary reason for this is because the literature disagrees on a set measurement. Verhaest and Omey (2006) support this perspective and admit that there is no uniform way of measuring overqualification. The problem is in figuring out how much education a job really requires (Vaisey 2006). There are four common methods for measuring overqualification outlined in the literature.

The job analysis (JA) method of measurement is the most common of the four. This method bases the required educational level on the occupational classification of job analysts. A well-known classification for occupations in the United States is the Dictionary of Occupational Titles (DOT). Utilizing the DOT is the most common method of measuring overeducation that originated with Eckhaus's (1964) and later Scoville's (1966) and Berg's (1970) utilization of the General Educational Development (GED) 
scale of the Dictionary of Occupational Titles to estimate the years of schooling required for average functional performance in an occupation in an objective way (Halaby 1994). This measurement of overqualification is based on a comparison between the educational attainment of each respondent and the amount of education necessary or likely to be utilized in his or her present occupation.

Following Berg (1970), estimates of the educational requirements of jobs are made using three scores: math, reasoning, and language, of the GED scale. The GED scale measures the functional requirements of jobs and is determined by an objective job analysis to determine the average performance in the specific tasks of the jobs (Eckhaus 1964; Scoville 1966; Berg 1971; Burris 1883; Livingstone 2004; Vaisey 2006). Table 1 outlines how the GED score of the occupation is transferred into required schooling needed for a job:

\begin{tabular}{ll} 
Table 1 & $\begin{array}{c}\text { GED Educational Requirement } \\
\text { Conversion }\end{array}$ \\
GED & Educational Requirements \\
\hline 1,2 & $0-11$ years \\
3 & 12 years \\
4 & $13-15$ years \\
5 & 16 years \\
6 & $17+$ From: Burris $(1983)$
\end{tabular}

Halaby (1994) describes weaknesses of this procedure in that there is no consensus on the way of converting the scores of jobs on the six-point GED scale to parallel years-ofschooling scores. The GED scale estimates the mean years of required schooling in an occupation that is constructed by aggregating jobs, and because of this, it is ignoring the differences in the average years of required schooling across jobs within an occupation (Halaby 1994). Also, some have questioned whether the GED scale measures what it 
purports to measure (Halaby 1994). Though this may be the case, the JA method using the GED scale is still the most accepted measurement amongst sociologists for measuring overqualification (Eckaus 1964; Scoville 1966; Berg 1970; Burris 1983; Clogg and Shockey 1984; Halaby 1994; Livingstone 2004; Vaisey 2006).

Direct self-assessment (DSA) is a more subjective way of measuring overeducation. This can be accomplished by asking the respondents whether or not they feel they are overqualified for their jobs (Halaby 1994). A major drawback of DSA is that it is subjective (Halaby 1994). There is no information on the required level of education the job requires, and an employee can simply respond that they feel overqualified and will be counted as such (Halaby 1994).

Indirect self-assessment (ISA) asks respondents the educational level that is required for their job (Verhaest and Omey 2006). Overqualification using this method is measured by comparing the job's educational level with the actual educational attainment of the respondent (Verhaest and Omey 2006). The problem with this method of measurement is the fact that there are large differences in the question that is utilized on which the measure is based, which can yield varying results (Verhaest and Omey 2006).

A fourth way of measuring overqualification is known as the realized matches (RM) method (Verhaest and Omey 2006). This method is a measure that bases the required educational level on the distribution of the educational levels of the workers within each occupation (Verhaest and Omey 2006). This method defines someone as overqualified if his or her educational level is more than one standard deviation above the mean educational level within the respondent's given occupation (Verhaest and Omey 2006). The RM method is criticized on the fact that the job level is inwardly related to the 
capacity of overqualification, and there have been complaints that using one standard deviation from the mean can be too conservative and an arbitrary measurement of overqualification (Verhaest and Omey 2006).

There seems to be problems with how overqualification is measured since there is no uniform way (Omey and Verhaest 2006). Rubb (2003) found significant differences in results of overqualification between the different measures of it. Measures of overqualification usually assume that the skills that workers bring to their jobs were acquired through schooling, and only through schooling (Halaby 1994). Measures of overqualification also assume that the structure of the relationship linking schooling to skills remains relatively fixed over the short run (Halaby 1994).

Other issues with measures of overqualification exist. One is that they are based on a hard, ultimately misleading distinction between the worker and the job (Halaby 1994). Measurements of overqualification have also been criticized for not taking into account the variation of skills between one worker and another (Halaby 1994). Furthermore, measures of overqualification take no account of workers' preferences for the skills they would use, yet all workers acquire ability, experience, schooling, and other job skills throughout their time in the workforce (Halaby 1994).

Again, we find in Omey and Verhaest (2006) and other literature that no uniform way of measuring overqualification exists (Burris 1983; Halaby 1994; Feldman and Turnley; 1996; Vaisey 2006). Rubb (2003) found significant differences in the different measures of overqualification (Omey and Verhaest 2006). These different measures of overqualification can lead to varying results in the prevalence of overqualification (Omey and Verhaest 2006). The application of alternative measures leads to different 
conclusions, and those conclusions with respect to the impact of overeducation should be approached cautiously and critically (Omey and Verhaest 2006). Feldman and Turnley (1994) applied the most common measures of overqualification listed above on their research. It was found that there was high inter-item correlation among the four overqualification measures (Feldman and Turnley 1994). So, while the most common measures of overqualification are significantly related, through previous research it is seen that the results yielded will vary. This can possibly be an argument to assert that the measurements are validly finding the concept of overqualification, even if the rate of overqualification with the different measures is conflicting. The main issue with the measurements of these concepts is that some rely on subjective means, while others rely on objective means. In addition, the varying measurements have led to researchers finding widely varying degrees of the prevalence in which they occur.

\section{History of Overqualification, Overeducation, and Underemployment}

The concepts of overqualification, overeducation, and underemployment emerged in the 1970s (Berg, 1970; Freeman 1975, 1976; Rumberger 1981; Clogg and Shockey 1984). Berg (1970) argued in his book (reissued in 2003) Education and Jobs: The Great Training Robbery, that educational expansion may have unintended negative consequences for society i.e. overqualification for those with a higher education. Berg (1970) attacked the faith the U.S. placed in education as a solution to social issues like poverty and inequality. Through a statistical analysis, Berg (1970) showed that the educational attainment of the labor force had grown quicker than their jobs required them to have. 
Numerous scholars have asserted that a college education is not worth what it once was (Berg 1970; Becker 1970; Smith 1986). Individuals will only invest in a college education so long as they perceive the benefits to outweigh the costs (Galper and Dunn, 1969; Smith 1986). Those of us who choose to attend college do so, not only for the education that we will receive in the process, but also for the life assurance in the form of economic and occupational stability. A college education will seem useful so as long as college graduates can earn more than those with a high school education (Smith 1986).

Since the identification of overqualification by Berg (1970) as a growing social concern few researchers, particularly sociologists, have studied overeducation, overqualification particularly in recent years (Vaisey 2006). In fact, there are fewer than ten sociological studies concerning the study of overqualification in the U.S. since 2000. The existing literature that does surround overqualification is primarily concerned with the consequences of overqualification, while paying less attention to what makes people overqualified to begin with.

While economic cycles may play a role in affecting overqualification, they cannot completely account for the large expansion of it over the last four decades (Vaisey 2006). Vaisey (2006) discovered that the average education of U.S. worker had increased by 1.75 years from 1972-2002 while the educational requirements of the average full-time job have increased by only 0.33 years. Autor and colleagues found similar results in their research to support the argument that the educational requirements of jobs have not grown significantly (2003)

Burris (1983), using the job analyst measurement of overqualification found that about 21.7 percent of full-time workers were overqualified for their jobs in 1977-78. The 
most interesting finding of Burris' (1983) study was the fact that he found that the most overqualified workers were not those with four-year college degrees, but amongst workers who had 13-15 years of schooling. Clogg and Shockey (1984) found the rate of overqualification to be growing, and quickly. Using the realized matches (RM) measurement of overqualification, Clogg and Shockey (1984) found that overqualification had risen from 7.8 percent in 1969 to over 14 percent in 1980 .

Livingstone (a Canadian sociologist 2004) used the JA method of measuring overqualification, but applied different methods of converting GED scores to required job educational requirements based on previous literature. Livingstone (2004) found the rate of overqualification to be quite severe. Livingstone (2004) found that the rate of overqualification in the U.S. had risen from 46 percent in 1972 to 62 percent in 1990. While this may be a liberal estimate of overqualification, the fact remains that all measurements of the issue consistently find that overqualification has been steadily climbing since the 1970s. The most recent American sociological article has found that overqualification has been steadily increasing since the early 1970s (Vaisey 2006).

Vaisey's (2006) paper had two objectives: first, to assess the prevalence and social distribution of overqualification in the U.S. labor market between 1972 and 2002; and second, to explore the effects of overqualification on several economic, social and political outcomes. This article used a job analyst approach to determine job qualifications because it asserts that this is the best method to assess underemployment in that it is less arbitrary and the best objective way of measuring overqualification (Halaby 1994; Cohn and Kahn 1995; Van der Velden and van Smoorenburg 1997; Vaisey 2006). 
It was found from a sample of over 18,000 people from 1972-2002 that overqualification has increased from 30 percent to near 55 percent of the full-time working population (Vaisey 2006). A more conservative measurement, only counting those who are three or more years overqualified, resulted in an estimate that overqualification has risen from 10 to 20 percent from 1972 to 2002 , which is still an alarming increase (Vaisey 2006).

In more recent years, Vaisey (2006) show that the rate of overqualification has risen to 20.3 percent for men between the years 1993-2002, and has increased to 19.8 percent for women (Vaisey 2006). For whites during the same period, the rate of overqualification was 19.4 percent, and for nonwhites 22.6 percent (Vaisey 2006). From Vaisey (2006) it can be seen that overqualification is a growing issue in the U.S. While it seems that most of the literature measuring overqualification has found it to be a significant, growing social issue, some literature questions the negative effects of overqualification, and whether or not it constitutes attention, or indeed is a social problem at all (Smith 1986).

Smith (1986) conducted two empirical sections to his paper, the first that considered the relationship between 1940 and 1980 and the growth in college educated Americans. The second analyzes the changes in income of college graduates between 1940 and 1980 (Smith 1986). Both show that declining returns to education hypothesis has not come true (Smith 1986). Smith (1986) held that even though there was a slow down in growth of jobs requiring a college education, college educated jobs still have a high salary. Smith (1986) also asserted that most were only overeducated in the narrowest sense. Also, the decline in returns to higher education has not been as great and as longstanding 
as once believed (Smith, 1986). While antiquated, it would seem that Smith studies show that the issues of overqualification are not relevant social issues.

In contrast to the opinion of Smith, most who have studied overqualification have found it to be a significant, relevant, and growing social issue (Berg 1970; Burris 1983; Halaby 1992; Vaisey 2006). The expansion of occupations that had characterized the decades after the 1940 s slowed after the 1970 s, while the growth of college-educated labor continued to quickly grow (Burris 1983; Clogg and Shockey 1984; Kalleberg and Sorensen 1973; Smith 1986.). Around the 1980s, American workers increasingly found that their acquired years of schooling significantly exceeded the levels of schooling that were historically typical of the occupations in which they were employed (Halaby 1994).

\section{The Predictors, Causes, \& Effects of Overqualification}

The predictors and/or causes of overqualification have not really been addressed, but there is literature that shows promise (Burris 1983; Feldman 1996). Though Feldman (1996) is cautious that accurate measurements for gauging overqualification exist he does posit several hypotheses about what variables may be significant in predicting overqualification.

Feldman (1996) suggests that economic factors have long been associated with overqualification. For example, Elder (1974) asserted that economic downturns, such as recessions and depressions impact overqualification because of the impact they have on the job market. Furthermore, Feldman (1996) suggests that economic policy mandating regulation of wages, benefits, and other worker protections may also influence overqualification. 
Career history is likely to influence individual risk of overqualification (Feldman, 1996). Those who have been laid off or unemployed for a long period may have a higher rate of overqualification because they may be marginalized in the job market making it harder for them to find a job that fits their qualifications (Feldman 1996). Also, those who have been unemployed or laid off for longer periods of time may have a higher risk of being overqualified simply because they are forced to take jobs to meet financial needs, increasingly the likelihood of overqualification. (Sandler 1988; Tan, Leana \& Feldman 1994).

Job search methods may also impact overqualification (Feldman 1996). Those who start looking for jobs earlier and who invest more energy in their search may have a lower risk of overqualification (Feldman 1996). Also, a willingness to geographically relocate can reduce one's risk of overqualification (Leana \& Feldman 1994; Feldman 1996).

Finally, demographics may provide significant insight into understanding what predicts overqualification (Feldman, 1996). Burris (1983) found that younger workers, nonwhites, and males, and those from "working class backgrounds" had the highest likelihood of being overqualified. Feldman also found that overqualification will be higher in women, racial minorities, and age, but will be negatively associated with education (Feldman, 1996). Furthermore, Vaisey (2006) found that overqualification was most prevalent among men, though the rate of overqualification appears to be more equitable among the sexes in most recent years. In addition Vaisey (2006) also found that non-whites had a higher rate of overqualification then their white counterparts.

There has been much more research revolving around the effects of overqualification. Overqualification is hypothesized to have a negative effect on job attitudes, job 
satisfaction, work commitment, job involvement, and motivation (Berg 1970; Freeman 1971; Rumberger 1981; Clogg and Shockey 1984; Borgen, Amundson and Harder 1988; Burris 1983; Locke \& Latham 1990; Feldman 1996; Vaisey 2006). Also, it is predicted that overqualification will have a negative effect on life satisfaction, optimism, selfesteem, and overall psychological well-being (Feather \& O'Brien 1986a, 1986b; Feldman 1996). Overqualification may also hurt attitudes towards careers (Burris, 1983; Borgen, Amundson and Harder 1996). Overqualification may also have a damaging effect on relationships with spouses, children and friends (Newman 1993; Zvonkovi 1988;

Feldman 1996). Finally, overqualification may influence left political view, and achievement ideology (Vaisey 2006). 


\section{THEORY}

Through the works on overqualification, and due to the growing prevalence of the issue, it can be seen that human capital theory's evolutionary economy explanation of phenomenon is open to criticism. Because of this, other possible theoretical perspectives explaining the issue are needed, and may be found in conflict theories.

Human capital theory seems to be the most followed when offering an explanation of the relationship between education and jobs, especially among economists (Livingstone 1999; 2004). The central theme with human capital theory is that the aptitude for people to learn is something that is comparable with other natural resources in the capitalist production process (Becker 1964). Human capital theorists rely on the assertion that more schooling will lead to higher productivity, higher earnings, and thus, macroeconomic growth (Becker 1964). For Becker (1964), greater educational attainment is closely linked to a higher per-capita earning, and social progress.

We live in a society where it is perceived that an investment in formal education will lead us to jobs with higher pay and class status. Human capital theory is a perspective that Western economies are evolving into a knowledge-based economy where there will be adequate jobs that fit the knowledge of the workforce. Indeed, some Human Capital theorists link higher education to a better, evolving society (Becker, 1964). To Becker (1964) earnings greatly devalue the social productivity of those with a college 
education because they are only partly compensated for their effect on the development and spread of economic knowledge.

The main doubt with human capital theory is cast in light of the fact that while school enrollment in colleges have significantly expanded since 1970s while at the same time the growth of average incomes has slowed, and overqualification, or having more education than a job requires, has been recognized as a growing issue (Berg 1970; Clogg and Shockey 1984; Halaby 1994; Feldman 1996; Livingstone, 1999; 2004; Vaisey 2006). Under the perspective of human capital, the fact that there has been continual growth of the rate of overqualification documented since the 1970 s devalues the assertion that we are moving towards a more knowledge based economy where not only educational attainments are higher, but the educational requirements of jobs are higher as well. There have been efforts to revise human capital theory (Senge 1990; Nyhan 1991; Reich 1991; Beck 1992; Becker 1993; 1996), Yet the revisions of it still fail to account for increasing educational attainments, while there are diminishing jobs for them to use that education and skill they have obtained (Livingstone 1999; 2004).

Human capital theory fails to explain the growing prevalence of overqualification, and therefore, other theoretical explanations for the issue must be sought. Livingstone $(1999 ; 2004)$ asserts that insight into Marxist and Weberian theories of the relationship between educational attainments and jobs may offer a better, conflict theory perspective, and a theoretical orientation that may be helpful in explaining the growing rate of overqualification in the U.S.

The first conflict theory that tries to explain overqualification is found in Bowles and Gintis' (1976) correspondence theory. Their theory tries to specify and verify the 
relationships between educational attainment and its economic impact (Bowles and Gintis 1976). They assume that formal schooling in capitalist societies serves as stabilizing purpose by affirming the dominant social and cultural structures, and that this stabilizer serves to legitimize social inequality, and that this is possible in a capitalist society because of the lack of a democratic economy (Bowles and Gintis 1976; Livingstone, 1999; 2004).

Another conflict theory explanation of overqualification may come from Collins' (1979) and Thurow's (1975) emphasis of educational credentials in the process of occupational selection. Credentialists argue that overeducation is the result of the use of educational credentials as a way of legitimizing economic privilege (Collins' 1979; Thurow 1975; Burris 1983). In this view, while employers allocate the best jobs to those who have a higher education, there will be a pressure for higher education that is separate from the skill requirements of jobs or even in the changes in returns to those jobs (Collins 1979).

Bourdieu (1970) provides an explanation of the reproduction of social inequalities of through education. Bourdieu (1970) places a lot of attention on the cultural knowledge, and how sophisticated tools from better schools operate for those from more affluent backgrounds. Having access to the cultural tools provided by better schools leads to greater success for those from more affluent backgrounds than those from more working class origins (Bourdieu 1970). Bourdieu (1970) provides great insight into the discriminatory schooling conditions that those from working class backgrounds face (Livingstone, 1999; 2004). 
Collins (1979) rejects the thought that technological change requires constant skill upgrading. Also, Collins (1979) holds that people are concerned with gaining control of occupational power and income, not with using skills to maximize production, and therefore, under Collins, those workers with the best skills are not necessarily the best paid. Under Collins (1979) the overall structure of the modern occupational world can be seen as a range of variations in the possession of resources for controlling work conditions and appropriating the means of production. Collins (1979) ends up proposing a kind of credential plutocracy where the most mobile occupational communities negotiate among themselves for greater self-regulatory powers.

The theory surrounding the phenomenon of overqualification is clearly underdeveloped and very little of it provides insight into what may play into an increased risk of being overqualified. In addition, further theory is needed to help provide an understanding of overqualification as it relates to gender, and race (Livingstone 1999; 2004). While theory surrounding overqualification remains vague and underdeveloped, it can be seen through previous literature that the applicability of human capital theory in explaining overqualification is open to criticism. It is clear that a conflict theory perspective would assert that those from less affluent backgrounds with higher educational attainments are more likely to be overqualified.

The current rate of overqualification is higher than it was when the issue was first addressed (Vaisey 2006). The fact alone serves to delegitimize the assertions of human capital theory. While one theory that tries to explain overqualification has been open to criticism since scholars started addressing the issue of overqualification, the conflict 
theories attempting to explain the phenomenon have received no empirical attention. It is important that the conflict theories that are trying to explain the phenomenon are tested. 


\section{METHODOLOGY}

This study was be a secondary analysis of the pooled 1972-2010 General Social Surveys (GSS) that is obtainable through the Interuniversity Consortium for Political and Social Research website: www.icpsr.umich.edu/. The National Opinion Research Center (NORC) at the University of Chicago has conducted the GSS of around 1,500 respondents per sample in the years of 1972-1978, 1980, 1982-1991, 1993, 1994, 1996, $1998,2000,2002,2004,2006,2008$, and 2010 . The 1972-1974 samples followed a modified probability sample design. In the years $1977,1978,1980$, and 1982-2010, the GSS employed a full probability sample. The sample is collected from noninstitutionalized adults living in the U.S.

Following prior research in the area of overqualification (Burris 1983; Clogg and Shockey 1984; Halaby 1994; Vaisey 2006) would mean restricting the sample to those who work full-time. I separated myself from prior research on overqualification that restricts analysis to full-time employees and will be analyzing part-time and full-time workers, and their rates of overqualification. The rationale for this was that there has been a widespread increase in part-time employment since the 1970s (Livingstone 1999; 2004) and addressing those who are overqualified and working in part-time positions may provide a more interesting analysis and a richer understanding of the current issue of overqualification. Limiting the data this way creates a sample size of 32,911 workers who are full and part-time, 27,295 full-time workers, and 5,616 part-time workers. 
After the variables of interest (overqualification, age, parents' education, white, male, south, part-time, and married) had been isolated, looking at Table 2 we see the initial descriptive statistics for the variables. After reducing the data to just those respondents who were employed (either full or part-time), who were between the ages of 18 and 65 , who were included in the overqualification variable (which limits the data to those who answered occupational classification questions and educational attainment questions) it can be observed that the dataset is reduced to 31,124 from the original 55,087 a $43.5 \%$ reduction. This merits attention, and by looking at the original codebook we can see if this is a reduction that can be explained simply. Looking at the original codebook and data set it was observed that 27,295 respondents reported themselves as working full-time and 5,616 respondents reported themselves as working part-time, totaling 32,911 respondents in the workforce. This is a $5.4 \%$ reduction. This $5.4 \%$ difference between those respondents in the workforce, and the criteria reduction by age, work status, and overqualification information, and the 32,911 can most likely explained be due to lack of overqualification (occupational, and educational attainment) information.

Looking at Table 2 we see the variables Overqualification, Parents' Education, and Married have smaller sample sizes than that of the remaining variables. Parents'

Table 2 Descriptive Statistics of Variables of Interest (Before Imputation)

\begin{tabular}{|c|c|c|c|c|c|}
\hline Variable & $\mathrm{N}$ & Min. & Max. & Mean & Std. Dev. \\
\hline Overqualification & 31,124 & 0 (matched) & 1 (overqualified) & .4751 & .49939 \\
\hline Age & 31,124 & 18 & 65 & 39.34 & 11.841 \\
\hline $\begin{array}{l}\text { Parents' } \\
\text { Education }\end{array}$ & 28,241 & 0 & 20 & 11.1595 & 3.50842 \\
\hline White & 31,124 & 0 (non-white) & 1 (white) & .8186 & .38536 \\
\hline Male & 31,124 & 0 (female) & 1 (male) & .4422 & .49655 \\
\hline South & 31,124 & 0 (other region) & 1 (south) & .3483 & .47644 \\
\hline Part-Time & 31,124 & 0 (full-time) & 1 (part-time) & .1573 & .36413 \\
\hline Married & 31,120 & 0 (non-married $)$ & 1 (married) & .5630 & .49602 \\
\hline
\end{tabular}


education raises the most concern, as it is a $9.3 \%$ reduction in the data, which warrants attention. The respondents not having information on their parents' education is the most likely explanation for this $9.3 \%$ reduction in the data.

Running a Little's Missing Completely at Random (LMCAR) test provided useful as it allowed for imputation of the $9.3 \%$ reduction without parents' educational attainment information. After running this analysis, it was observed that the value of Chi-Square $=435.768$ with Sig. $=.000$. This meant that it was statistically significant and warranted a rejection of the null hypothesis that the data was missing completely at random. This means that the best imputation method for this data may have been multiple imputation. That said, for this draft, expectation maximization was used. Using

Table 3 Descriptive Statistics of Variables of Interest (After Imputation)

\begin{tabular}{lccccc}
\hline \multicolumn{1}{c}{ Variable } & $\mathrm{N}$ & Min. & Max. & Mean & Std. Dev. \\
\hline Overqualification & 31,124 & 0 (matched) & 1 (overqualified) & .4751 & .49939 \\
Age & 31,124 & 18 & 65 & 39.29 & 11.827 \\
Parents & 31,124 & 0 & 20 & 11.1311 & 3.33302 \\
Education & 31,124 & 0 (non-white) & 1 (white) & .8188 & .38520 \\
White & 31,124 & 0 (female) & 1 (male) & .4420 & .49664 \\
Male & 31,124 & 0 (other region) & 1 (south) & .3483 & .47644 \\
South & 31,124 & 0 (full-time) & 1 (part-time) & .1576 & .36440 \\
Part-Time & 31,120 & 0 (non-married) & 1 (married) & .5629 & .49604 \\
Married & & & &
\end{tabular}

the expectation maximization technique to impute data is a clear violation of a statistical assumption. That assumption being that expectation maximization is reserved for data that is MCAR. This means that there needed to be a further assessment of why the data is missing to discover if the data is missing at random (MAR) or not missing completely at random (NMCAR).

To do this, I looked at the data and found out how people with and without data available on parental education compare on various characteristics. Getting the 
descriptive statistics for the two groups and doing an independent sample t-test for the numerical variables education and age, and a chi-squared test for the categorical variables was done to determine any statistical significance of the difference between the two on different descriptive characteristics existed. For these purposes, a dummy variable, missingmapaeduc $(0=$ not missing parental educational information and $1=$ missing parental educational information) was created. From these analyses it was discovered that the data that was missing on parental educational information was not missing completely at random with those not overqualified, males, south, education of respondent, and age being statistically significant indicators of missing parental educational information.

After discovering the data that was missing on parental educational information was not missing completely at random, a different imputation technique was used in which missing parental educational information was replaced by the mean parental educational information, 11.1595. After running regression models based on this imputation technique it was discovered that the models did not differ significantly from the expectation maximization imputation technique, and for this analysis the data was imputed using the expectation maximization imputation.

Looking at the descriptive statistics in Table 3 we can see that this imputation was successful. Finally, we see that for the married variable $n=31,120$. This is very small reduction and can most likely be explained by respondents simply not answering the marriage question. After limiting the data to those respondents with information on all of the variables we get a final $\mathrm{n}=31,120$. 
This research used the General Educational Development (GED) scale developed by the U.S. Department of Labor to estimate educational requirements for each occupation. The GED scale allowed for a comparison between the educational attainment of each respondent and the amount of education necessary or required for their occupation (Burris 1983; Halaby 1994). Again, this has been the most consistent objective measurement of overqualification outlined in the literature (Eckaus 1964; Scoville 1966; Berg 1969; Burris 1983; Halaby 1994; Livingstone 1999, 2004; Vaisey 2006).

The GED scale uses three divisional scores, reasoning, math, and language, and averages these to assess the educational requirements of each respondent's occupation to determine a GED score for a given occupation (Vaisey 2006). The GED method bases the required educational level on the occupational classification of job analysts (Burris 1983; Groot and Maasen 2000; Vaisey 2006). A well-known job classification system for the U.S. is the Dictionary of Occupational Titles ((DOT) Vaisey 2006). Researchers have consistently used the DOT and its GED scale to estimate the years of education required for average functional performance in an occupation (Eckaus 1964; Scoville 1966; Berg 1969; Burris 1983; Clogg and Shockey 1984; Halaby 1994; Livingstone 1999, 2004; Vaisey 2006). The GED scores are converted to required education for occupations by utilizing the transformation outlined in Table 1 .

After determining the educational requirements for each occupation and comparing those with the educational level of the respondent, the prevalence of overqualification from 1972-2010 can be determined. Those with a higher educational level than that of their occupational educational requirement for functional performance on a job are seen as overqualified. 
The GSS uses 1970 and 1980 census occupational codes to label a respondent's occupation. The 1970 and 1980 census occupational codes contain approximately 1000 categories each. The DOT has over 14,000 occupational classifications and consists of almost every occupational category that exists in the U.S. This means that for my purposes and to use the GSS for them a conversion method from DOT codes to 1970 and 1980 census codes was necessary to utilize the rich information the GSS provides for the purposes of this research.

Luckily, such a "crosswalk" from DOT codes to 1970 and 1980 census codes exists. The National Crosswalk Service Center (NCSC) website (http://www.xwalkcenter.org/) provides a source of occupational crosswalks from the DOT to census occupational codes. The NCSC has been providing occupational information for over 25 years. The purpose of this organization is to "give effective and efficient use of occupational information." Utilizing the crosswalks provided by the NCSC provides an easy path to utilizing the GSS to measure educational requirements of occupations and thus overqualification.

Because the 1970 and 1980 censuses contain fewer occupational categories than the DOT, collapsing occupations is necessary. Again, the crosswalks from the NCSC do this for us, but because there are more than 14,000 DOT categories, finding the mean GED scores for many DOT occupational categories to fit one census category is necessary. Other researchers have successfully used very similar conversions in the recent past to gauge educational requirements for jobs using the DOT to census occupational code conversions (see Vaisey 2006). 
After determining mean GED scores for census occupational codes for both 1970 and 1980, overqualification of respondents in the GSS from 1972-2010 could be determined. First, a conversion of mean GED scores to years of educational requirements was used using the method seen in Table 1. After educational requirements for each census codes had been determined, assessing the equity between the educational requirements and the respondent's actual educational attainment can be accomplished by subtracting the educational requirements of the job from the educational attainment of the respondent. Looking at those respondents who have more education than their job requires will allow an assessment of the rate of overqualification from the years 1972-2002. This will help to determine if the rate of overqualification is still rising in recent years. If Vaisey (2006) and other researchers are correct it can be expected that the rate of overqualification has continued to grow in most recent years.

The second part of this analysis of overqualification used using binary logistic regression to help determine what possible predictors significantly in increase of overqualification. Though basic demographical information has been used in prior research (Eckaus 1964; Scoville 1966; Berg 1969; Burris 1983; Clogg and Shockey 1984; Halaby 1994; Vaisey 2006) to determine a higher likelihood of overqualification using variables such as sex, age, and race, no American sociologist has looked at other possible predictors. While these demographic variables will not be ignored in this analysis, a look at other possible variables that may increase the likelihood of overqualification will be assessed.

Looking at previous research and using the credentialist theory helped to lead to variables that may be significant predictors of overqualification in the U.S. Verhaest and 
Omey (2010) are avid researchers of overqualification in Europe (Verhaest and Omey $2003 ; 2006 a ; 2006 b ; 2010)$. It is through an analysis of Verhaest and Omey (2010) and other previous research and using the credentialist perspective of overqualification that possible predictors of overqualification were addressed and used in this analysis.

Possible predictors tested in this analysis include the demographic variables listed above, and others such as region of residence, marital status, part-time employment, and parents' education.

Determining what variables increase the propensity to be overqualified/overeducated/underemployed is necessary, especially if following the findings of previous research the rate of those who are overqualified has been increasing. Knowing the factors and variables that increase the likelihood of overqualification can help lead to a better understanding of the problem, and find possible solution. Using previous research and the credentialist lens, the following hypotheses have been formed:

As parents' education increases, the respondent's risk of overqualification will decrease.
Respondents have parents that have a higher education will easier access to networks that facilitate finding jobs that match their educational skills (Verhaest and Omey 2010). This also fits the credentialist perspective that those from more affluent backgrouds will have easier access to the best jobs (Collins' 1979; Thurow 1975; Burris 1983; Livingstone 1999; 2004).
Marital Status/Relationship Status

Being married will decrease the risk of being overqualified.
People who are married or cohabitating with a partner generally are older, and this can decrease the likelihood of overqualification (Vaisey 2006).
Age
As age increases, overqualification will decrease.
As jobs in certain areas decline, those with less experience, the young, will have a harder time finding jobs to fit their educational skill set (Feldman, 1996). 


\begin{tabular}{lll}
\hline Sex & $\begin{array}{l}\text { Women will have a lower } \\
\text { rate of overqualification } \\
\text { than men. }\end{array}$ & $\begin{array}{l}\text { Though the gap between men and women is } \\
\text { expected to shrink over time, it is expected that } \\
\text { women will be more overqualified than men } \\
\text { (Vaisey 2006). }\end{array}$ \\
\hline Race & $\begin{array}{l}\text { Nonwhites will have a } \\
\text { higher rate of } \\
\text { overqualification than } \\
\text { whites. }\end{array}$ & $\begin{array}{l}\text { Minorities' access to managerial positions and } \\
\text { other high status jobs is still highly } \\
\text { underrepresented as of 2002 (Tomaskovic-Devy } \\
\text { and Stainback. 2007). }\end{array}$ \\
\hline Region of Residency & $\begin{array}{l}\text { Regions with higher rates } \\
\text { of unemployment will have } \\
\text { higher rates of } \\
\text { overqualification. }\end{array}$ & $\begin{array}{l}\text { Those who live in regions with a shorter supply of } \\
\text { highly educated workers will have a lower rate of } \\
\text { overqualification. }\end{array}$ \\
\hline
\end{tabular}

Part-time
Those with part-time employment will have a greater risk of overqualification.
Those who have higher educational attainments may have a higher rate of overqualification due to "job-settling" in order to meet financial demands. 


\section{FINDINGS}

\section{Rate of Overqualification: 1972-2010}

Looking at Graph 1 we can see the rate of overqualification from 1972-2010. In $1972,33.4 \%$ of the workforce was overqualified, or had more skills or education than their jobs required them to have. Looking at Graph 1 it is seen that while there is an overall upward trend of the workforce being overqualified, that trend does fluctuate from year to year. The rate of overqualification hit its peak in 1996 at $55.6 \%$. Finally, for the last year of analysis, 2010, the rate of overqualification was at $54.5 \%$. So, while it can be seen that the rate of overqualification clearly fluctuates on a year-to-year basis, the overall trend is that the rate of overqualification is rising, and has been at or above $50 \%$ of the workforce since the early 1990s. This is an alarming overall increase in the rate of overqualification, and is consistent with the findings of other research.

Looking at the rate of overqualification by the sex of the respondent can be located in Graph 2. Looking at Graph 2, it is quickly noticed that the line representing females is much more erratic than the line representing males. It is also noticed that women had the highest rate of overqualification for either sex in 2004 at $62.8 \%$. The most curious aspect of Graph 2 is the fact that it cannot easily be determined which sex is more likely to be overqualified for a given year. This is interesting in the fact that previous research on the rate of overqualification holds that women are less likely to be overqualified than men. Men had their highest rate of overqualification in 1996 at 54.6. 


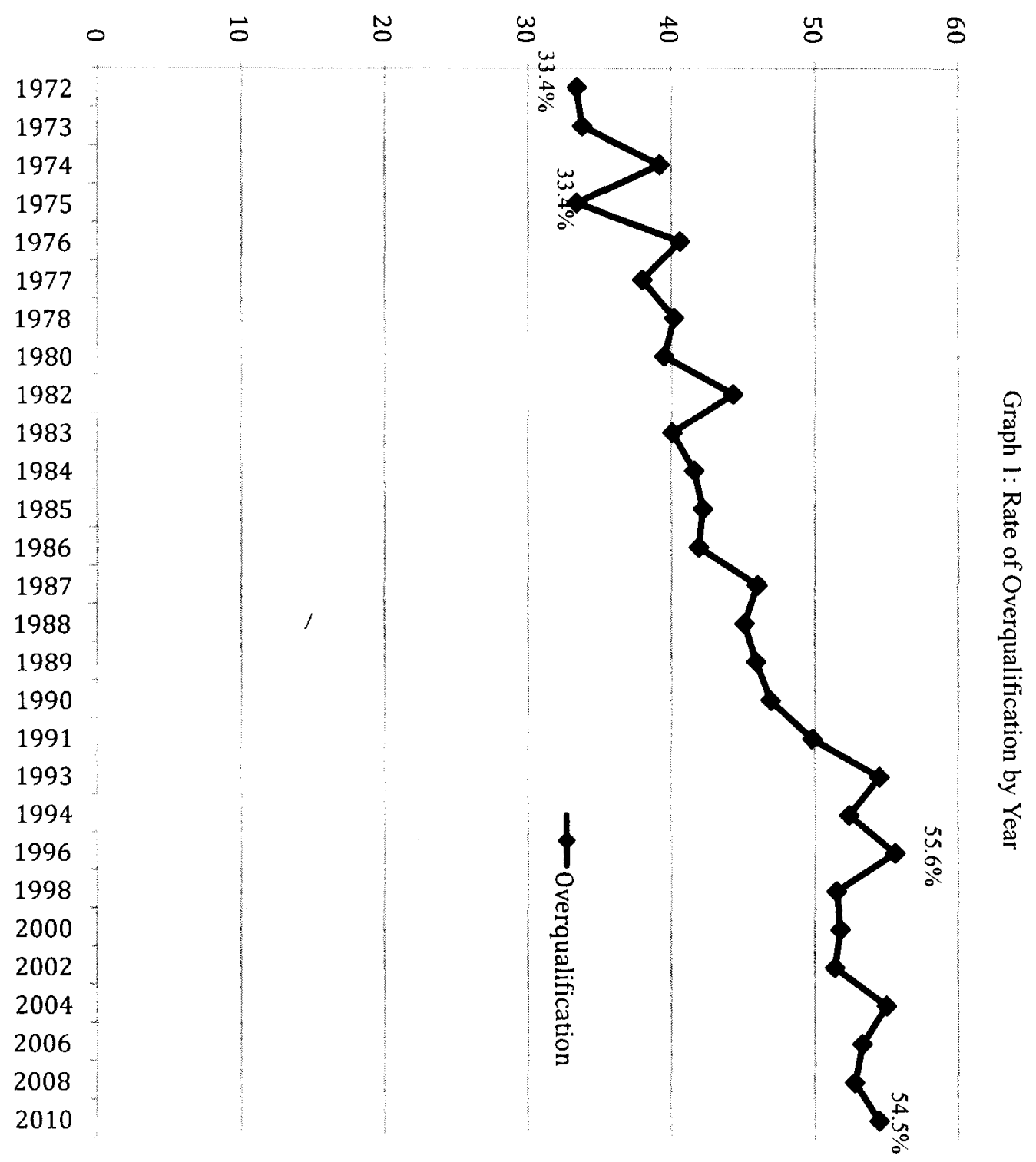




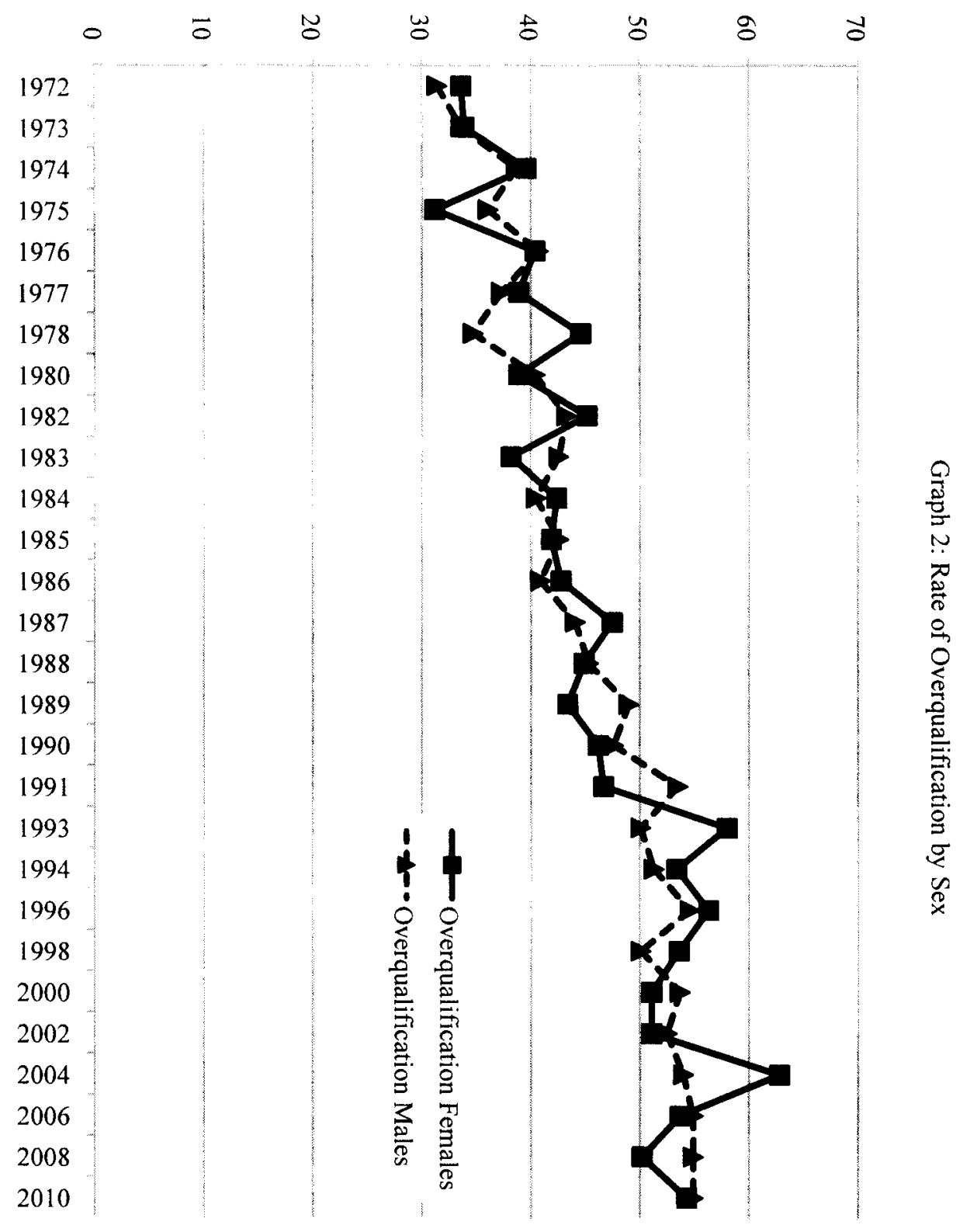




\section{IV's Relationship to Overqualification}

Looking at Table 5 it is observed that there is not a statistically significant relationship between the sex of the respondent, thereby confirming suspicions that may have been raised looking at Graph 2. This is an interesting finding in that previous research holds that men are more likely to be overqualified than women. This could possibly be explained by the fact that previous research such as Vaisey (2006) was

Table 5 Chi-Square Test: IV's Relationship to Overqualification 1972-2010

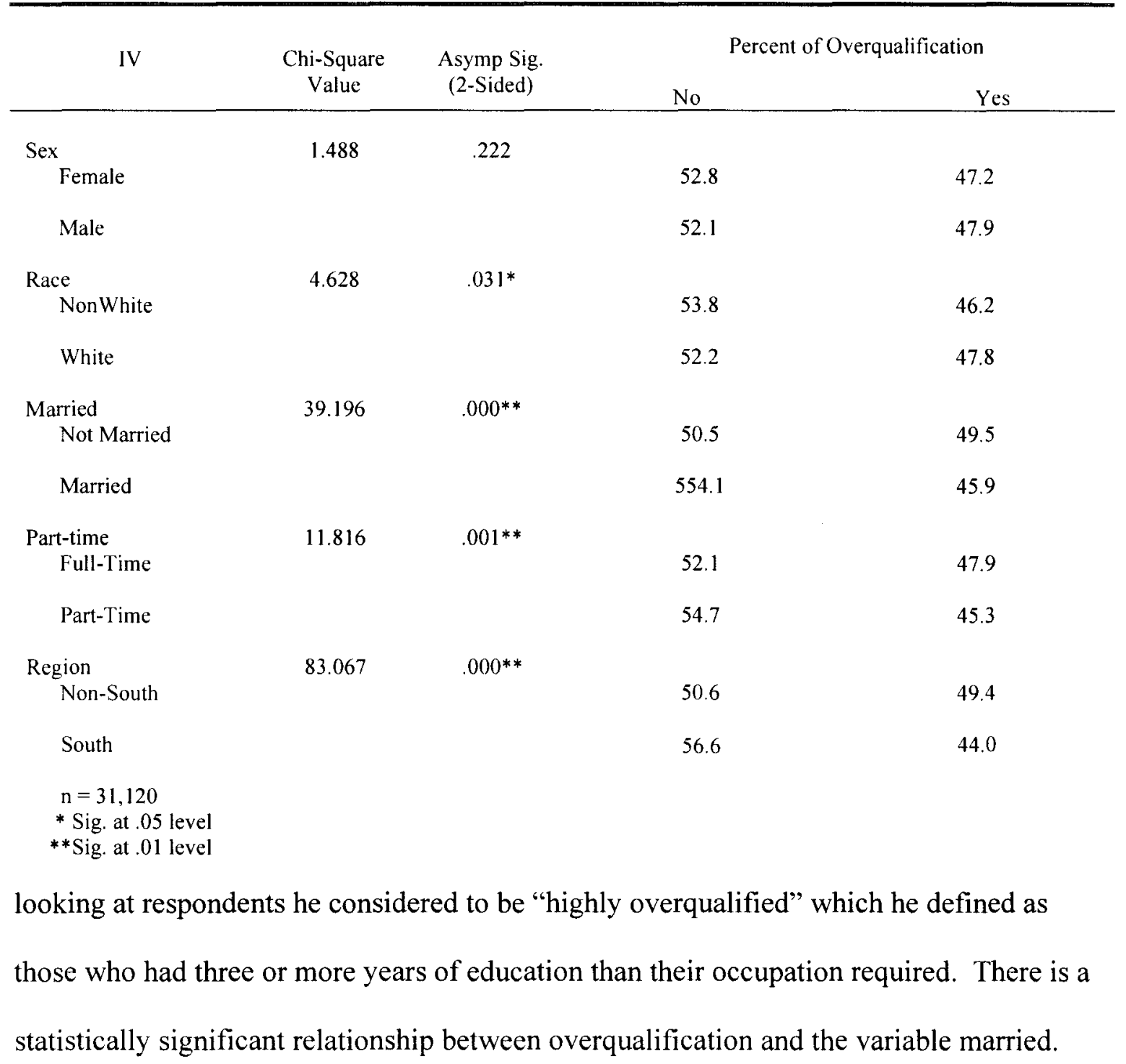


There is a statistically significant relationship between overqualification between overqualification and the variable part-time. Finally, there is a statistically significant relationship between the dependent variable overqualification and the region variable, south.

Table 6 Independent Sample T-Test: IV's Relationship to Overqualification

\begin{tabular}{|c|c|c|}
\hline IV & T-Value & Sig. (2-tailed) \\
\hline Parents' Education & -44.459 & $.000^{* *}$ \\
\hline Age of Respondent & 8.952 & $.000^{* *}$ \\
\hline $\mathrm{Age}^{2}$ & 10.276 & $.000^{* *}$ \\
\hline \multicolumn{3}{|c|}{$\begin{array}{l}n=31,120 \\
* * \text {. Correlation is Significant at the } 0.01 \text { level (2-tailed) }\end{array}$} \\
\hline \multicolumn{3}{|c|}{ After running independent sample t-tests of the mean of differences between } \\
\hline \multicolumn{3}{|c|}{ overqualification based on the independent variables parents' education, age of } \\
\hline \multicolumn{3}{|c|}{ respondent, and age-squared, the null hypotheses that the differences in the variances of } \\
\hline \multicolumn{3}{|c|}{ the independent variables are not equal was rejected because the p-value on all of the } \\
\hline \multicolumn{3}{|c|}{ variables was less than .05 . Looking at the t-test, it is known that it is testing the null } \\
\hline \multicolumn{3}{|c|}{ hypotheses that there is no difference in the means of parents' education of the } \\
\hline \multicolumn{3}{|c|}{ respondent, age, and age-squared of the respondent and overqualification. Since the p- } \\
\hline \multicolumn{3}{|c|}{ value is less than .05 in all of the tests, the null hypotheses were rejected that there was } \\
\hline no difference in & to indica & tionship between \\
\hline
\end{tabular}




\section{Binary Logistic Regression Findings}

Using binary logistic regression to examine the effects of overqualification on the independent variables, age, age $\mathrm{e}^{2}$, white $(0=$ nonwhite, $1=$ white $)$, $\operatorname{sex}(0=$ male, $1=$ female), married $(0=$ nonmarried, $1=$ married $)$, parents' education, part-time, and south $(0=$ Non-South U.S., $1=$ Southern U.S. $)$ leads to some interesting findings. Using Table 7 at the first regression output from 1972-2010 it is noted that the Nagelkerke r-square value is 0.086 . This means that $8.6 \%$ of the variance in overqualification can be explained by the predictors age, age ${ }^{2}$, white, sex, married, parents' education, part-time, and south. We reject the null hypotheses that age, age ${ }^{2}$, married, parents' education, parttime, and south are not significant predictors of overqualification. We fail to reject the null hypothesis that the variables white, and sex are not significant predictors of overqualification.

There is something interesting happening with the age and age-squared variables. As age increases, the likelihood of overqualification also increases. This is curious as previous literature holds that as age increases the propensity to be overqualified decreases. Because the score is so low, it can be assumed that age has a very small effect on the dependent variable, but the positive relationship is interesting. Age-squared has a negative effect on overqualification and, again, since the value is so small, .001, we can assume that the effect is not that large. Because of this curious, conflicting relationship between the two age variables, a further analysis of age on overqualification is warranted and will be discussed later.

As one becomes married, the risk of overqualification decreases. We can assume that this will be a small effect on overqualification. As parents' education increases, the 
likelihood of being overqualified also increases. This is curious and may be evidence to support rejection of the credentialist theory behind overqualification, which leads us to believe that as parent's education increases, the risk of overqualification decreases. Although the value of this variable $B=.159$ means we can assume that parents' education will not have a large effect on overqualification, but it must still be noted that it has the largest effect on overqualification among all of the independent variables.

Table 7 Binary Regression Analysis of the Effects of IV's on Overqualification

\begin{tabular}{|c|c|c|c|c|c|}
\hline & B & S.E. & Wald & Sig. & $\operatorname{Exp}(B)$ \\
\hline \multicolumn{6}{|l|}{$1972-2010$} \\
\hline Age & .061 & .007 & 74.274 & .000 & 1.063 \\
\hline $\mathrm{Age}^{2}$ & -.001 & .000 & 69.846 & .000 & .999 \\
\hline White & .042 & .031 & 1.861 & .172 & 1.043 \\
\hline Sex & .003 & .024 & .014 & .905 & 1.003 \\
\hline Married & -.072 & .024 & 8.664 & .003 & .931 \\
\hline Parent Educ & .159 & .004 & 1566.065 & .000 & 1.172 \\
\hline Part-Time & -.122 & .033 & 13.961 & .000 & .885 \\
\hline South & -.143 & .025 & 33.127 & .000 & .867 \\
\hline $\begin{array}{l}\text { Constant } \\
(\mathrm{r}-\text { square }=.086) \\
(\mathrm{n}=31,120)\end{array}$ & -2.997 & .148 & 408.716 & .000 & .050 \\
\hline \multicolumn{6}{|l|}{$1972-1982$} \\
\hline Age & .025 & .015 & 2.829 & .093 & 1.025 \\
\hline $\mathrm{Age}^{2}$ & -.001 & .000 & 7.925 & .005 & .999 \\
\hline White & .086 & .065 & 1.739 & .187 & 1.090 \\
\hline Sex & -.011 & .051 & .042 & .837 & .989 \\
\hline Married & -.089 & .056 & 2.510 & .113 & .915 \\
\hline Parent Educ. & .131 & .008 & 242.139 & .000 & 1.140 \\
\hline Part-Time & -.069 & .071 & .935 & .334 & .933 \\
\hline South & -.205 & .054 & 14.122 & .000 & .815 \\
\hline $\begin{array}{l}\text { Constant } \\
\qquad(\mathrm{r}-\mathrm{square}=.091) \\
(\mathrm{n}=7,212)\end{array}$ & -1.857 & .303 & 37.476 & .000 & .156 \\
\hline \multicolumn{6}{|l|}{$1983-1992$} \\
\hline Age & .085 & .014 & 35.205 & .000 & 1.089 \\
\hline $\mathrm{Age}^{2}$ & -.001 & .000 & 38.439 & .000 & .999 \\
\hline White & .001 & .056 & .000 & .984 & 1.001 \\
\hline Sex & .053 & .047 & 1.254 & .263 & 1.054 \\
\hline Married & -.124 & .049 & 6.287 & .012 & .884 \\
\hline Parent Educ. & .151 & .008 & 328.953 & .000 & 1.163 \\
\hline Part-Time & .026 & .063 & .169 & .681 & 1.026 \\
\hline South & -.195 & .051 & 14.931 & .000 & .823 \\
\hline $\begin{array}{l}\text { Constant } \\
\qquad \begin{array}{l}(\mathrm{r}-\text { square }=.088) \\
(\mathrm{n}=7,873)\end{array}\end{array}$ & -3.311 & .299 & 122.341 & .000 & .036 \\
\hline \multicolumn{6}{|l|}{ 1993-2002 } \\
\hline Age & .069 & .013 & 27.909 & .000 & 1.072 \\
\hline
\end{tabular}




$\begin{array}{lccccc}\text { Age }^{2} & -.001 & .000 & 22.542 & .000 & .999 \\ \text { White } & -.006 & .063 & .009 & .925 & .994 \\ \text { Sex } & -.077 & .043 & 3.245 & .072 & .926 \\ \text { Married } & .025 & .043 & .338 & .561 & 1.025 \\ \text { Parent Educ. } & .143 & .007 & 374.579 & .000 & 1.154 \\ \text { Part-Time } & -.201 & .059 & 11.762 & .001 & .818 \\ \text { South } & -.163 & .044 & 13.782 & .000 & .850 \\ \text { Constant } & -2.919 & .282 & 107.430 & .000 & .054 \\ \quad(\mathrm{r}-\text {-square }=.064) & & & & & \end{array}$

2003-2010

$\begin{array}{llllll}\text { Age } & .043 & .016 & 7.377 & .007 & 1.044 \\ \text { Age }^{2} & .000 & .000 & 3.843 & .050 & 1.000 \\ \text { White } & .041 & .064 & .413 & .520 & 1.042 \\ \text { Sex } & .002 & .053 & .001 & .970 & 1.002 \\ \text { Married } & .025 & .054 & .210 & .647 & 1.025 \\ \text { Parent Educ. } & .157 & .009 & 284.852 & .000 & 1.170 \\ \text { Part-Time } & -.245 & .072 & 11.520 & .001 & .783 \\ \text { South } & -.093 & .054 & 3.035 & .081 & .911 \\ \text { Constant } & -2.782 & .338 & 67.576 & .000 & .062\end{array}$

The relationship between part-time and overqualification is negative. Being employed part-time decreases the likelihood of overqualification. This too is an interesting finding as it was hypothesized that those in part-time employment would have a higher risk of being overqualified. Because the $\mathrm{B}$ value is so low for the part-time variable, one can anticipate that this will be a small effect. Finally, the relationship between living in the south and overqualification is negative. This means that those living in the south have a lower likelihood of being overqualified. This is consistent with the hypothesis that those who live in regions with a lower supply of high educational attainment workers will have a lower risk of overqualification. We can assume that the variable south will not have a large effect on the dependent variable overqualification due to the fact that the B value is so low. From this, the regression equation for the first regression is:

$\ln (O D D S)=-2.997+.061($ Age $)-.001\left(\right.$ Age $\left.^{2}\right)-.072($ Married $)+.159($ Parent' $s$ Educ $)-.122($ Parttime $)-.143($ South $)$

Moving to the second regression that applies to the years 1972-1982 similar relationships are found that were outlined in the larger regression analysis. We reject the 
null hypotheses that age ${ }^{2}$, parents' education, and south are not significant predictors of the dependent variable, overqualification. We fail to reject the null hypotheses that age, white, sex, married, and part-time are not significant predictors of the dependent variable, overqualification. It is also quickly noticed that the variable that will have the largest effect on the dependent variable is south. This is a negative effect meaning that those who lived in the South between the years of 1972 and 1982 had a lower likelihood of being overqualified, which is consistent with the finding from the regression including all years. From this, the regression equation:

$\ln (O D D S)=-1.857-.001\left(\right.$ Age $\left.^{2}\right)+.131\left(\right.$ Parents $\left.^{\prime} E d u c\right)-.205($ South $)$.

Looking at the third regression containing the years 1983-1992 we reject the null hypotheses that age, age ${ }^{2}$, married, parents' education, and south are not significant predictors of the dependent variable, overqualification. We fail to reject the null hypotheses that sex and part-time are not significant predictors of the dependent variable, overqualification. From this regression, it is also noted that the independent variable, south will have the largest effect on overqualification. This is again a negative effect meaning that those who lived in the south between the years of 1983 and 1992 had a lower likelihood of being overqualified for their jobs than who lived in other regions of the U.S. The regression equation for the third regression is: $\ln (O D D S)=-3.311+.085($ Age $)-.001\left(\right.$ Age $\left.^{2}\right)+.151\left(\right.$ Parents $\left.^{\prime} E d u c\right)-.195($ South $)$.

Looking at the fourth regression concerning the years 1993-2002 warrants rejection of the null hypotheses that age, age ${ }^{2}$, parents' education, part-time, and south are not significant predictors of the dependent variable, overqualification. We fail to reject the null hypotheses that the independent variables white, sex and married are not 
significant predictors of the dependent variable, overqualification. It is also observed that the variable, part-time, will have the most effect on the dependent variable, overqualification. This is a negative relationship meaning that those who work part-time are less likely to be overqualified than are those who have full-time employment. From this, the regression equation for the fourth regression is:

$$
\ln (O D D S)=-2.919+.069(\text { Age })-.001\left(\text { Age }^{2}\right)+.143\left(\text { Parents' }^{\prime} \text { duc }\right)-.201(\text { Parttime })-.163(\text { South })
$$

Looking at the fifth and final regression for the remaining years 2003-2010 we fail to reject the null hypotheses that the independent variables, age, age-squared, parents' education, and part-time are not significant predictors of the dependent variable, overqualification. We fail to reject the null hypotheses that white, sex, married, and south are not significant predictors of the dependent variable, overqualification. It is also noted that part-time has the largest effect on the dependent variable and that this relationship is negative. Again, this means that those who have part-time employment are less likely to be overqualified than those working in full-time jobs. The regression equation from the final regression model is:

$$
\ln (O D D S)=-2.782+.043(\text { Age })+.000\left(\text { Age }^{2}\right)+.157(\text { Parents' Educ })-.245(\text { Parttime })-.093(\text { South })
$$

From the binary regression analysis it is noted that none of the models are very good with the second model being the best with a r-squared value of .091. Parents' education is the most consistent significant predictor of the dependent variable overqualification. This is a curious relationship though as the models consistently show that as parents' education increases there is higher risk of overqualification. Another curious relationship is occurring with the relationship between part-time employment and overqualification. The regression analysis indicates that the rate of overqualification is 
lower for those in part-time employment as compared to those who are full-time workers. In addition, sex, nonwhites, and marriage are not significant predictors of overqualification. This is interesting, especially since previous literature seems to indicate that those with the highest likelihood of overqualification are young, white, and male. The findings of these regression analyses seem to indicate that this is not the case. This could possibly be explained by the fact that this analysis concentrated more on those who are simply overqualified as opposed to other research (Vaisey, 2006) that focuses on what they consider to be "highly-overqualified" meaning three or more years of overqualification.

\section{A Further Analysis of Age as a Predictor}

Looking at a potential curvilinear relationship between overqualification and age may provide an interesting analysis. Isolating the rate of overqualification by age for all years is a way to investigate this potential relationship. After isolating the pertinent data, a curve estimation analysis of the effect of age on overqualification can be assessed based on a quadratic analysis of the data.

Table 8 Quadratic Regression Analysis: The Effect of Overqualification by Age

\begin{tabular}{cccccc}
\hline R-Square & D.F. & F & Sig & Beta Coefficient0 & Beta Coefficient1 \\
\hline .324 & 2 & 10.797 & .003 & 1.660 & -2.034
\end{tabular}

Looking at table 8 , it can be seen that this model is a good fit for the data. This is supported by the fact that the F statistic is relatively high, and we have a p-value of .003 . Looking at Graph 3 it is noticed that in younger years, about $18-28$, the rate of overqualification rapidly rises. Then from about age 29 on, the rate of overqualification 
steadily declines. This can potentially be explained by the fact that a lot of people ages 18-28 are still acquiring education or just completing it. Upon entry into the workforce, younger people may take entry-level positions, or jobs not requiring as much skill as they possess. After age 28 , the decreasing likelihood of overqualification can possibly be explained by upward mobility. This would imply that as workers get older, they get pay raises and the scope of their employment increases. Put simply, as a person gets older, after age 28 or so, the requirements of their jobs start to more closely match the skill and education that they possess. Another possible explanation for this relationship is that as people are expanding their education, many work in jobs that may not match their education, increasing the likelihood of overqualification from age 18-28.

Graph 3 Quadratic Regression: The Effect of Overqualification by Age

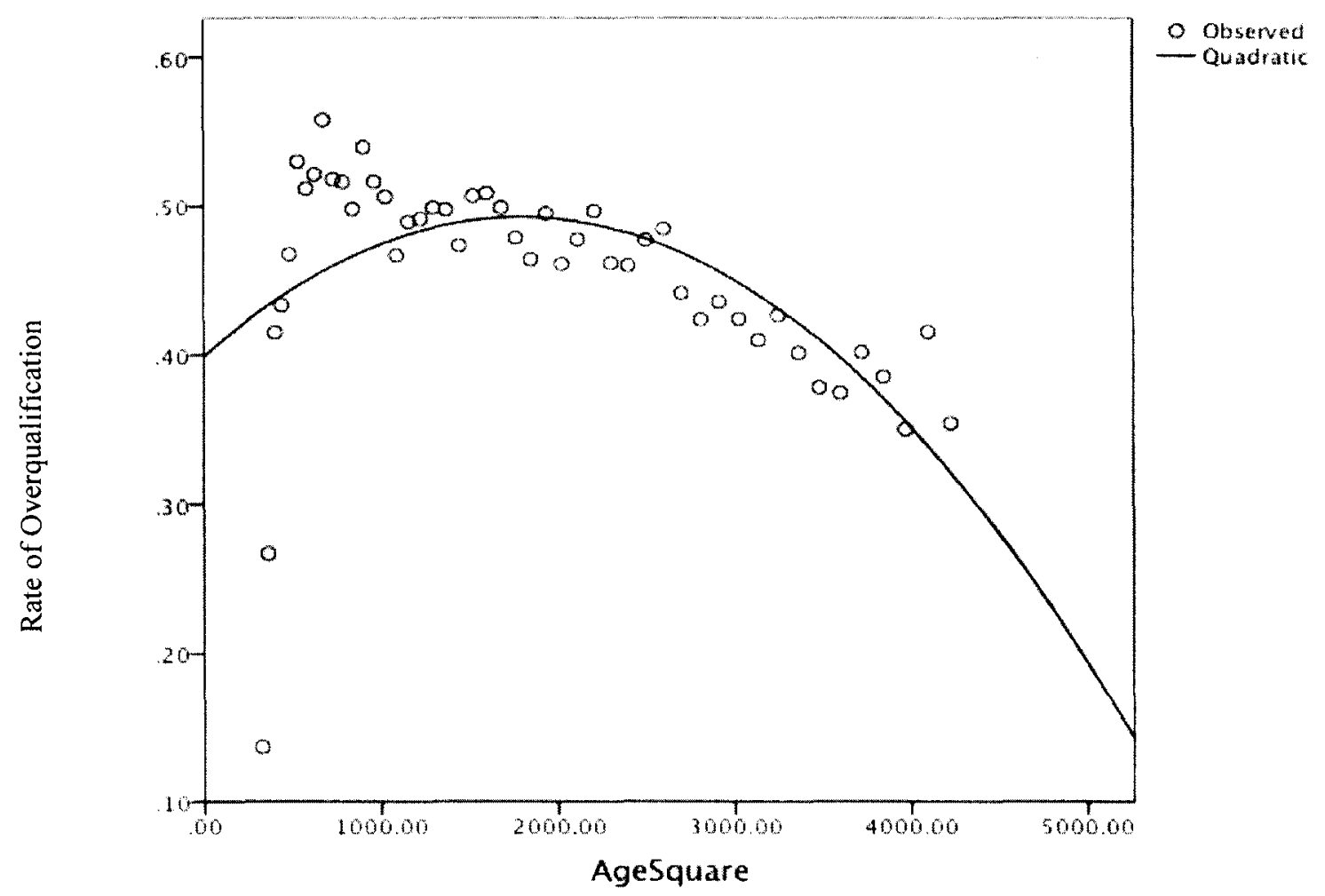




\section{DISCUSSION}

Looking back at the original hypotheses stated in Table 4 we can see that more than a few of the original hypotheses are rejected. One of the most interesting findings is the fact that parents' education was consistently found to have a positive effect on the propensity of overqualification. This seems to contradict Collins' and the credentialist argument of overqualification that would lead us to believe that as parents' educational attainment increases, the risk of overqualification is lower. The variables age, sex, and race were found to not be significant predictors of overqualification. This is interesting in that Vaisey (2006) and other researchers held that those who are young, white, and male have the highest risk of being overqualified. The hypotheses surrounding those variables are unfounded in light of the finding that none of these variables were found to be statistically significant predictors of the dependent variable, overqualification.

The curvilinear relationship between overqualification and age is quite interesting. Previous research seems to indicate that as we get older our risk of overqualification decreases. The reality is that through our mid-twenties our risk of overqualification increases and then after about age 28 it steadily declines. Perhaps this can be explained by asserting that while we are in our early adult years our educational attainment is quickly rising. Upon entry to the workforce, we seek out entry-level jobs that may not have a broad scope of employment and may not pay what our educational attainment could and should pay. As we move through our careers our scope of 
employment expands and our pay should increase. This means that as we get older the responsibilities and pay of our job will more likely match that of our educational attainment.

Region of residency (represented by the dummy variable, south) is quite interesting. While those in the south are consistently found to be less likely to be overqualified, except in the last regression model, the effect that region has on overqualification is getting smaller with time. This seems to support our hypothesis that those living in regions where there is a higher supply of higher educational attainment workers will also have a higher rate of overqualification, however this relationship seems to be decreasing with time. Other regions should be explored in future research. Finally, it was interesting to see that those working part-time positions are less likely to be overqualified. While this variable was not always statistically significant in predicting overqualification it is still interesting in that it was expected that a higher rate of overqualification would be found among part-time employees. With this, the initial hypothesis that those with part-time employment will have a higher risk of overqualification is rejected.

Overqualification merits more attention from sociologists. The literature shows that sociologists can offer a more complete understanding of the issue, and that understanding can help lead to more complete solutions of the problem of overqualification. While the issue of overqualification may have once been central to sociologists, the lack of recent literature on the subject, particularly in the U.S. combined with findings of growing rates of the issue, warrants new research aimed at measuring, predicting, and addressing the consequences. 
There are clear disparities when it comes to measuring overeducation, overqualification, and underemployment. Some find that it does not seem too big of a social problem, and may just be part of the economic cycle. Most seem to be skeptical of this assertion and believe that this is not only a significant social problem, but also one that is growing at an alarming rate. Indeed, the disparities of the research are indications that one should come to this subject with neutrality and caution. That said, all measurements of the issue are correlated with one another, and all find overqualification to be quite high, sometimes exceeding 50 percent of the labor force in most recent years. Through the findings in this research it is shown that the rate of overqualification remains a large, and continuously growing problem.

Though all measurements of overqualification have shown a close relation to one another a more universal system of measuring the issue needs to be implemented. Furthermore, the measurement techniques themselves should be put to the test to determine which is the best, even though most research seems to find that the JA method of measurement, used in this research, is the best. Without this area of research being standardized, more widely varying results will keep surfacing, and this opens the window to critics claiming overqualification is not a severe social problem. Overqualified workers are in serious need of attention, not only from sociologists, but also from media and policy makers. The fact that media and policy makers concentrate on low unemployment rates for stability of the workforce is a narrow approach to understanding workforce stability. Overqualification should and could add a fuller understanding of workforce health. 
Most studies concentrate on the consequences of overqualification while ignoring or skimming over predictors and determinants other than basic demographical information. While very important, more empirical research is needed all around, but especially on the predictors of overqualification. This seems to be one of the ripest areas of study for this niche of research. The more we know about what causes overeducation, overqualification, and underemployment, the more that can be done to ameliorate the negative consequences of it. In addition, a longitudinal study of those who find themselves overqualified could be done to determine the long-term consequences, and this would help to add to a better psychological and sociological understanding. The research here shows that overqualification is a problem and that this problem has grown significantly since 1972 . This knowledge could help to better understand if this is just a temporary market cycle, or if this is in fact a growing problem in the labor market today.

The final area of research that is also deserving of more attention is that of theory. The limited amount of theoretical research on this topic is alarming. This atheoretical understanding of underemployment, overeducation, and overqualification opens this social issue to more criticism. Until more valid theories on the reasons and antecedents of this subject surface, the research will remain in its infancy. The lack of American sociological literature surrounding the problem and nature of overqualification is odd. The fact that almost all of the literature shows an alarming increase in the rate of workers that are overqualified clearly warrants a new, diligent approach to a sociological interpretation of the issue. 


\section{REFERENCES}

Battu, H. Belfeld, C. and Sloane. 2000. "How Well Can We Measure Graduate Overeducation and Its Effects?" National Economic Review 171(1): 82-93.

Beneito, P. et al. 2002. "Over/Undereducation and Specific Training in Spain," in Heijke and Muyskens (ed.) Education and Training in a Knowledge-Based Economy: 191-214.

Büchel, F. 2002. "The Effects of Overeducation on Productivity in Germany-The Firms' Viewpoint. Economics of Education Review 21(3): 263-275.

Büchel, F and Mertens, A. 2004. "Overeducation, Undereducation, and the Theory of Career Mobility." Applied Economics 36(8): 803-816.

Beck, U. 1992. Risk Society: Towards a New Modernity. London, England: Sage.

Becker, G. 1970. Human Capital. Chicago: University of Chicago Press.

Becker, G.S. 1996. "Human Capital: One Investment Where America is Way Ahead," Business Week (March 11).

Berg, I. 1970. Education and Jobs: The Great Training Robbery. Boston, MA: Beacon Press.

Borgen, W.A., Admundson, N.E. and Harder, H.G. 1988. "The Experience of Underemployment." Journal of Employment Counseling, 25, 149-159.

Bowles, S. and Gintis, H. Schooling in Capitalist America: Educational Reform and the Contradictions of Economic Life. New York, NY: Basic Books. 
Burris, V. 1983. "The Social and Political Consequences of Overeducation." American Sociological Review 48:454-467.

Carnoy, M. And Levin, H. 1985. Schooling and Work in the Democratic State. Stanford, CA: Stanford University Press.

Clogg, C., and Shockey, J.W. 1984. "Mismatch between Occupation and Schooling: A Prevalence Measure, Recent Trends and Demographic Analysis." Demography 21: $235-257$.

Cohn, E. and Kahn, S.P. 1995. "The Wage Effects of Overschooling Revisted." Labor Economics 2:67-76.

Collins, R. 1979. The Credential Society: An Historical Sociology of Education and Stratification. New York, NY: Academic Press.

Eckhaus, R.S. 1964. "Economic Criteria for Education and Training." Review of Economics and Statistics 46:181-190.

Elder, G., Jr. 1974. Children of the Great Depression: Social Chaning in Life Expreiences. Chicago: University of Chicago Press.

Feather, N.T. and O'Brien, G.E. 1986. "A longitudinal Analysis of the Effects of Employment, Different Patterns of Employment, and Unemployment of SchoolLeavers." British Journal of Psychology, 77: 459-479.

Feldman, D. C. 1996. "The Nature, Antecedents and Consequences of Underemployment". Journal of Management. 22(3): 385-407.

Feldman, D.C. Turnley, W.H. 1995. "Underemployment Among Recent Business College Graduates." Journal of Organizational Behavior 16: 691-706. 
Freeman, R. 1971. The Labor Market for College-Trained Manpower. Cambridge, MA: Harvard University Press.

Galper, H. and Dunn, R.M. 1969. “A Short-Run Demand Function for Higher Education in the U.S." Journal of Political Economy. 15:124-142.

Gibbons, R. 2005. "What is Economic Sociology and Should Any Economists Care?" Journal of Economic Perspectives 19(1): 3-7.

Greenberger, E. and Steinberg, L. 1986. When Teenagers Work, New York: Basic Books. Groot, W and Brink, H.M. 2000. "Overeducation in the Labor Market: a Meta Analysis." Economics of Education Review 19(2): 149-158.

Halaby, C. 1994. "Overeducation and Skill Mismatch". Sociology of Education 67(1): 47. Retrieved from Proquest Database on April 1, 2011.

Kallegberg, A.L. and Sorensen, A.B. 1973. "The Measurement of the Effects of Overtraining on Job Attitudes." Sociological Methods and Research 2:215-238.

Livingstone, D.W. 2004. The Education-Jobs Gap. Aurora, Ontario: Garamond Press. Locke, E.A. \& Latham, G.P. 1990. "Work Motivation and Satisfaction: Light at the edn of the Tunnel." Psychological Science, 1:240-246.

Newman, K.S. 1993. Declining Fortunes: The Withering of the American Dream. New York: Basic Books.

Nyhan, B. 1991. Developing People's Ability to Learn: A European Perspective on Self Learning Competency and Technological Change. Brussels, Spain: European Interuniversity Press.

Reed M. 2011. Student Debt and the Class of 2010. Retrieved October 30, 2011, from, Projectonstudentdebt.org. 
Reich, R. 1991. The Work of Nations: Preparing Ourselves for $21^{\text {st }}$ Century Capitalism. New York, NY: Vintage.

Rubb, S. 2003. "Overeducation in the Labor Market: A Comment and Re-Analysis of a Meta-Analysis." Economics of Education Review 22(6): 621-629.

Rumberger, R.W. 1981. "The Rising Incidence of Overeducation in the U.S. Labor Market." Economics of Education Review 1(3): 293-314.

Sandler, S.B. 1988. "Dislocated Workers: A Response." Journal of Employment Counselling, 25:146-148.

Scoville, J.G. 1966. "Education and Training Requirements for Occupations." Review of Economics and Statistics 48:387-394.

Senge, P. 1990. The Fifth Discipline: The Art and Practice of the Learning Organization. New York, NY: Doubleday.

Smith, H.L. 1986. "Overeducation and Underemployment: An Agnostic Review." Sociology of Education 59:85-89.

Student Loan Debt Clock. 2011. Retrieved March, 2011, from http://www. finaid.org/loans/studentloandebtclock.html.

Sullivan, T.A. and Hauser, P.M. 1979. "The labor Utilization Framework: Assumptions, Data and Policy Implications." National Commission on Employment and Unemployment Statistics Report, (Vol. 1): Counting the Labor Force (Concepts and Data Needs). Washington, D.C.: U.S. Government Printing Office. 
Tan, G.Y., Leana, C.R. \& Feldman, D.C. 1994. "A Longitudinal Study of Predictors of Job Loss Coping Strategies." Ci Preceedings of the National Academy of Management: 68-72.

Vaisey, Stephen. 2006. Education and its Discontents: Overqualification in America 1972-2002. Social Forces 85(2): 835-864.

Verhaest, D. and Omey, E. 2006. "The Impact of Overeducation and its Measurement." Social Indicators Research 77(3): 419-448.

Van der Velden, R.K.W. and Smoorenburg, M.S.M. 1997. "The Measurement of Overeducation and Undereducation: Self-Report vs. Job-Analyst Method." Research Centre for Education and the Labor Market. Working Paper No. ROARM_1997/2E, Maastricht University, Maastricht.

Zvonkovic, A.M. 1988. "Underemployment: Individual and Marital Adjustment to Income Loss. Lifestyles: Family and Economic Issue 9:161-178. 


\section{CURRICULUM VITAE HENRY TED CURTIS}

528 Warnock Street, Louisville, KY 40217 502-299-3290

Hcurti6648@gmail.com

\section{RESEARCH INTERESTS}

- Sociology of Education: The growing problem of educational debt caused by student loan policies

- Sociology of Work and Occupation: Overqualification and its predictors

\section{EDUCATION}

- Master of Arts in Sociology from the University of Louisville May 2012, with areas of concentration in Sociology of Education, Sociology of Work and Occupation, and Contemporary Social Theory

- Bachelor of Science in Paralegal Studies from Sullivan University December 2009, graduated summa cum laude

- Cumulative GPA $3.98 / 4.0$

\section{TEACHING EXPERIENCE}

- Graduate Teaching Assistant Sociology University of Louisville Spring 2012

- Guest Lecturer for Social Theory 320 on Critical Theory and Poststructuralism (Instructor: Daniel Weinstein)

- Fall 2011

- Summer 2011

- Spring 2011

- Guest Instructor for Introduction to Sociology 201

- Fall 2011 (Instructor: Angela Orend)

- Class Facilitator for Social Policy 625 on Policy Theory and Educational Policy (Instructor: Dr. Lauren Heberle)

- Fall 2011

- Class Facilitator for Contemporary Social Theory 615 on Legitimation Crisis by Jürgen Habermas (Instructor Dr. Patricia Gagné)

- Spring 2011 
THESIS AND OTHER WRITINGS

- Measuring and Predicting Overqualification from 1972-2010: A Secondary Analysis of the Pooled General Social Survey

- Student Loan Policy: A Critical Look into the Exponential Growth of Student Loan Debt from 1965 to Present

- The Comorbidity of Substance Abuse and Mental Health

\section{WORK EXPERIENCE}

- Highland Coffee Company, Supervisor of up to four employees Oct. 2008 - Present

- Volunteer with Dare to Care Food Bank Feb. 2010 - Dec. 2010

- Internship with Barry Moore, Commonwealth Attorney 115 West Main Street LaGrange Kentucky 40202 Oct. 2008- Jan. 2009

- Café Perusa, Server Captain / Bar Consultant/Supervisor of up to eight employees February 2008 - Oct. 2008

- Hero's New York Pizza Pub Kitchen Supervisor of up to four employees July 2007 - February 2008

- Highland Coffee Company, Barista Supervisor June 2006 - July 2007

- Danielle's Restaurant, Front of House Manager of eight employees March 2006 - January 2007

- Azalea Restaurant, Server Captain February 2004 - March 2006 